\title{
Soybean field outlook: water use efficiency and Bradyrhizobium japonicum
}

\begin{abstract}
At the plant field level traditional definitions of water use efficiency (WUE) contain nonbeneficial component of water consumed - evaporation. This is one of the reason for the very big difference between WUE at the leaf and cenosis level (up to 30 times). That is why, without a doubt, the main way to increase WUE at the cenosis level must be due to the practices that reduce the soil water evaporation. Other component of WUE is yield and seed productivity per unit of plant leaf surface. For soybean local introducing of suspension of Bradyrhizobium japonicum with clay minerals in soil not only at sowing, but also at reproductive stages of ontogenesis, may be promising tool of yield increasing.
\end{abstract}

Keywords: soybean, water use efficiency, Bradyrhizobium japonicum
Volume 8 Issue I - 2020

\begin{abstract}
Kharchuk OA
The laboratory of Plants Nutrition and Water Regime, Institute of Genetics, Physiology and Protection of Plants, Moldova

Correspondence: Oleg Andreevich Kharchuk, The laboratory of Plants Nutrition and Water Regime, Institute of Genetics, Physiology and Protection of Plants, Chisinau, Moldova, Tel (+373) 69245257, Email kharchuk.biolog@mail.ru
\end{abstract}

Received: December 30, 2019 | Published: January 16, 2020
Abbreviations: $B$. japonicum, nitrogen fixing bacteria Bradyrhizobium japonicum; DAP, day after planting; E, soil evaporation; ET, evapotranspiration; ha, hectare; kg, kilogram; LA, leaf area per plant; mm, millimeter; $\mathrm{T}$, transpiration; WUE, water use efficiency

\section{Introduction}

The efficient use of limited water resources is an urgent issue for the Republic of Moldova. In field experiments at the level of cenosis water-use efficiency (WUE) is defined as yield (Y) divided by applied water. $^{1}$ As the measure of applied water or water consumption of the crop usually used the evapotranspiration (ET)-the mass of water evaporated in the cenosis during the growing season by the soil (evaporation, E) together with plants (transpiration, T). E is included in water requirement since Briggs and Shantz (1913), ${ }^{2}$ in view to practical difficulties to estimate separately beneficial (T) and nonbeneficial (E) consumption of water. In connection with the use of portable gas exchange analyzers (simultaneously $\mathrm{CO}_{2}$ and $\mathrm{H}_{2} \mathrm{O}$ ), it was proposed to evaluate WUE at the leaf level as a ratio of carbon dioxide assimilation (A) to water consumed, expressed as transpiration (T); the time-scale for defining WUE can be instantaneous (i). ${ }^{3}$

In addition to water consumption another component of WUE is the yield. The use of nitrogen-fixing bacteria Bradyrhizobium japonicum (B. japonicum) can be a means of increasing the soybean yield. Nitrate-N has disadvantages to increase yield. At first, nitrate reduces nodulation by 6 times. ${ }^{4}$ Secondly, when using nitrate, vigorous preanthesis growth can increase plant transpiration, at the expense of soil evaporation, and lead to a higher $\mathrm{C}$ fixation, but structural carbohydrate laid down earlier in the growing season is not readily mobilized to the grain, and receiving nitrate- $\mathrm{N}$ did not result in increased harvest index. ${ }^{5}$ In our study we set two objectives: 1) in one field experiment with soybean to determine WUE at the leaf level and at the level of cenosis; 2) in other field experiment to determine the effect of late (at the reproductive stages of plant ontogenesis) introduction into the soil of B. japonicum on some morphophysiological reactions of soybean plants. For these purposes, in 2019 two field experiments were carried out: 1) with the determination of yield and ET for calculating WUE at the level of cenosis, as well as determining instantaneous WUE at the leaf level with a portable gas analyzer; 2) microexperiment with late (70 DAP) local introduction of rhizobia into the soil under plants with the assessment of the stages of ontogenesis and seed productivity of the leaf area per plant with the observation of later nodulation.

The experimental site was located in Chisinau, Republic of Moldova, at the field of the Experimental Station of the Institute of Genetics, Physiology and Protection of Plants. The average (20012018) precipitation for period May-August is $221 \pm 4 \mathrm{~mm}$. During the experiment, the site examined value was nearly to this average, 200 $\mathrm{mm}$. The objects of the study were soybean plants Glycine max L. (Merr.) of variety Aura, the main variety in the Republic of Moldova. Seeds of the 2018 harvest were taken for sowing. A randomized experiment was in 4 replicates (plots of $3,6 \mathrm{~m}^{2}$ with density 20 plants $\mathrm{m}^{-2}$, distance between rows $0,50 \mathrm{~m}$ ). Measurements of leaf gas exchange parameters was carried out with a portable gas analyzer ADC BioScientific LCpro-SD (Great Britain). Soil samples for determining the water content (by drying at $105^{\circ} \mathrm{C}$ to constant weight) were taken at sowing and harvesting (in a layer of $0-150 \mathrm{~cm}$ with an interval of $10 \mathrm{~cm}$ ) to determine ET as the sum of soil water balance and precipitation for vegetation period in soybean cenosis). Several other determinations of soil water content in layer $0-150 \mathrm{~cm}$ were made at bare soil field for determining $\mathrm{E}$ (as the sum of soil water balance and precipitation). The microexperiment with late local introduction of rhizobia into the soil under plants was carried out in 4 different rows (repetitions) of $2 \mathrm{~m}$, with $3 \mathrm{~m}$ long intermediate plant rows without introducing in soil $B$. japonicum and clay mineral between plots with introducing in soil or only bentonite or bentonite with $B$. japonicum. On 70 DAP $(04.07 .2019)$ the soil was artificially enriched by population of $B$. japonicum strain RD2. Pure culture of cells $B$. japonicum strain $\mathrm{RD}_{2}$ was provided by Dr. L. Onofrash (Institute of Microbiology and Biotechnology, Republica Moldova, Chisinau). In the experiments, we used highly dispersed clay mineral bentonite, provided by Dr. O. Bolotin (Institute of Geology and Seismology, Republica Moldova, Chisinau). A suspension of B. japonicum with bentonite was prepared. During preparation, the ratio of bentonite with rhizobia was $10^{-4} \mathrm{mg}$ of bentonite/bacterial cell. Inoculation rate 
was $2 \cdot 10^{6}$ B. japonicum strain $\mathrm{RD}_{2}$ cells (in $100 \mathrm{ml}$ of water) per plant. Distance in row between plants was $10 \mathrm{~cm}$. In the control variant, the culture of rhizobacteria was not added to the suspension of clay mineral, which was introduced in soil as separate doses, each in 100 $\mathrm{ml}$ of water.

\section{WUE on the leaf and cenosis levels}

Acording to meaurements of leaf transpiration and $\mathrm{CO}_{2}$ assimilation on soybean plants in field, instantaneous WUE (A/T) at leaf level was $15,6 \pm 0,3 \mathrm{~g} \mathrm{CO}_{2} / \mathrm{kg} \mathrm{H}_{2} \mathrm{O}$ (Table 1).

Table I Leaf transpiration (T), $\mathrm{CO}_{2}$-assimilation (A) and instantaneous WUE (A/T) for soybean variety Aura at leaf level in field (20I9, 97 DAP)

\begin{tabular}{lll}
\hline $\mathbf{T}, \mathbf{m m o l ~} \mathrm{H}_{2} \mathrm{O} \mathrm{m}^{-2} \mathbf{s}^{-1}$ & $\mathbf{A}, \boldsymbol{\mu m o l ~} \mathrm{CO}_{2} \mathbf{m}^{-2} \mathbf{s}^{-1}$ & instantaneous WUE (A/T), $\mathbf{g ~ C O}_{2} / \mathbf{k g ~ H}_{2} \mathrm{O}$ \\
\hline $2,09 \pm 0,12$ & $13,33 \pm 0,86$ & $15,6 \pm 0,3$
\end{tabular}

The amount of precipitation for the 2019 vegetation season is approximatively $200 \mathrm{~mm}$. During this period, in soybean cenosis soil water reserves in the $0-150 \mathrm{~cm}$ layer decreased by $128 \mathrm{~mm}$. The evapotranspiration value is $200+128=328 \mathrm{~mm}$. The soybean yield was $164,5 \pm 10,0 \mathrm{~g} \mathrm{~m}^{-2}$ or $0,50 \pm 0,03 \mathrm{~g}$ seed $\mathrm{kg}^{-1}$ of water for evapotranspiration. This value corresponds to the literature WUE value for soybean fields, $0.6-1.0 \mathrm{~kg}$ grain $\mathrm{m}^{-3} \mathrm{ET}$ water ${ }^{6}$ and 30 times less than instantaneous WUE (A/T) at leaf level. To assess the magnitude of evaporation, we determined the change in soil water reserves at the bare soil field. From the time of sowing (April 26, 2019 ) to July 22,2019 ( 87 DAP), the soil water reserves of bare soil decreased by $35 \mathrm{~mm}$. Rains ( $80 \%$ of which in 2019 were less than 20 $\mathrm{mm}$ ) did not lead to an increase in water reserves of bare soil (these reserves even decreased). Accounting precipitations of $153 \mathrm{~mm}$ for may-July 2019, evaporation (bare soil) for 87 days of 2019 (counting from the sowing) was $188 \mathrm{~mm}$ (average $\sim 2 \mathrm{~mm}$ day-1). It is important that in the cenosis during the first half of the growing season, the leaf canopy cannot significantly reduce the evaporation losses of water Non-beneficial losses of available water of $200 \mathrm{~mm}$ - this is very much, more than half of the precipitation amount $(318 \mathrm{~mm})$, needed for a maximum soybean WUE. ${ }^{7}$ For example, for nearly 40x106 ha of soybean fields in USA $100 \mathrm{~mm}$ corresponds to 40 billions $\mathrm{m}^{3}$ liters of potentially potable water. That is why, without a doubt, the main way to increase WUE at the cenosis level must be due to the practices that reduce the soil water evaporation.

\section{The late local introduction of $B$. japonicum into the soil near plants}

1.5 months after the introducing of bentonite and B. japonicum in soil, the developmental stage was determined according to Fehr, Caviness (1977). ${ }^{8}$ The stage of 10 plants in each of 4 repetitions was taken in account. 17.08.2019 (113 DAP) in both variants stage of ontogenesis was the same, $5.4 \pm 0.1$. The leaf surface of reference plants was measured non-destructively several times per season (last time, August 23). Seed productivity of plant leaf surface was determined as seed weight per plant at harvest (16.09.2019) divided on plant leaf surface area (in $\mathrm{dm}^{2}$ ) 23.08.2019 (119 DAP), including already fallen leaves: these values in both variants were the same,

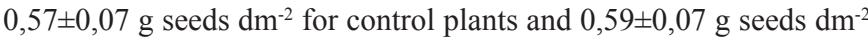
for plants after introducing $B$. japonicum in soil. Thus, late addition of $B$. japonicum does not show (at least 43 days after inoculation) plant developmental shift. When harvesting, plants of two variants in study differed in nodulation: more nodules are on the plant roots with introducing B. japonicum in soil (Figure 1).

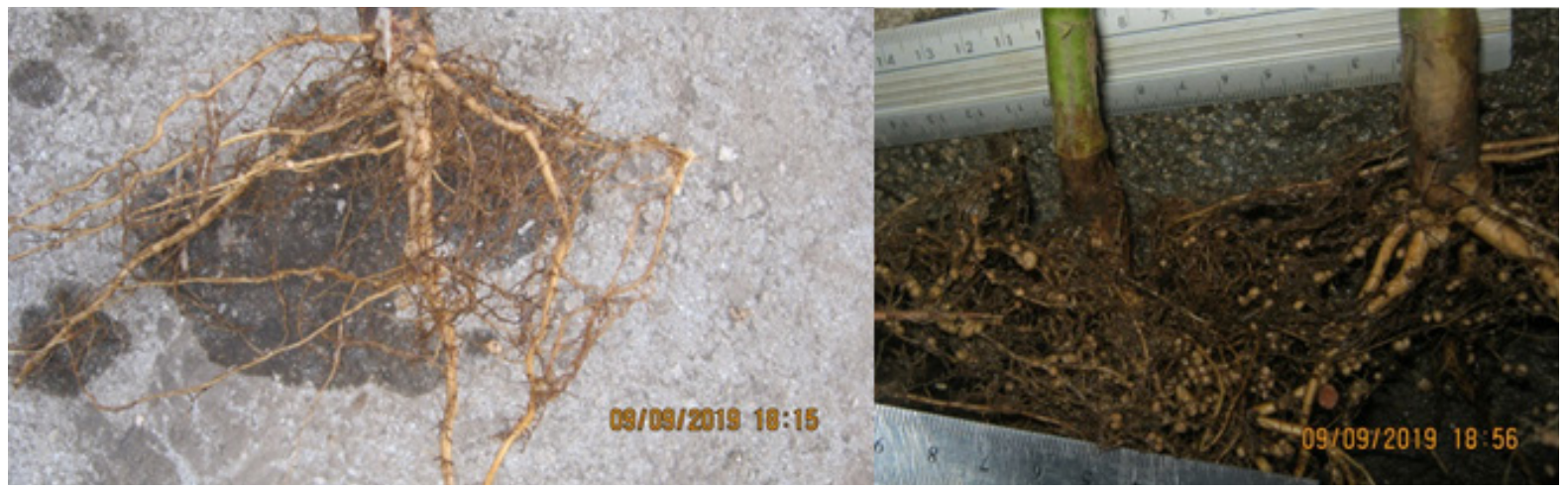

Figure I The effect of late (70 DAP) introducing bentonite and B. japonicum in soil on soybean root nodalization: on the left-bentonite only (control); on the right-bentonite with B. japonicum.

\section{Acknowledgments}

None.

\section{Conflicts of interest}

Author declares no conflict of interest.

\section{References}

1. Perry C, Steduto $\mathrm{P}$, Allen RC, et al. Increasing productivity in irrigated agriculture: Agronomic constraints and hydrological realities. Agricultural Water Management. 2009;96(11):1517-1524.

2. Briggs LJ, Shantz HL. The water requirements of plants. II. A review of the literature. United States Department of Agriculture Bureau of Plant Industry; $1913.96 \mathrm{p}$. 
3. Sinclair TR, Tanner CB, Bennett JM. Water-Use Efficiency in Crop Production. BioScience. 1984;34(1):36-40.

4. van Noorden GE, Verbeek R, Dinh QD, et al. Molecular Signals Controlling the Inhibition of Nodulation by Nitrate in Medicago truncatula. Int J Mol Sci. 2016;17(7):1060.

5. Unkovich M, Baldock J, Forbes M. Variability in harvest index of grain crops and potential significance for carbon accounting: examples from Australian agriculture. Adv Agron. 2010;105:173-219.
6. Sadras VO, Grassini P, Steduto P. Status of water use efficiency of main crops. SOLAW Background Thematic Report - TP07. Food and Agriculture Organization of the United Nations; 2012. 42 p.

7. Dietzel R, Liebman M, Ewing R, et al. How efficiently do corn- and soybean-based cropping systems use water? A systems modeling analysis. Global Change Biology. 2016;22(2):666-681.

8. Fehr WR, Cavines CE. Stages of Soybean Development. Cooperative Extension Service, Agriculture and Home Economics Experiment Station, Iowa State University: Ames, Iowa, USA; 1977. 12 p. 